\title{
ОСОБЛИВОСТІ ПЕРЕКЛАДАЦЬКОЇ ПРАКТИКИ ЯК ФОРМИ ОРГАНІЗАЦЇ̈ НАВЧАННЯ СТУДЕНТІВ ЗАКЛАДУ ВИЩОЇ ОСВІТИ ТЕХНІЧНОГО СПРЯМУВАННЯ
}

\author{
Матвіїв-Лозинська Ю. О. \\ кандидат педагогічних наук, доцент, \\ доцент кафедри іноземних мов \\ Національний університет «Львівська політехніка» \\ вул. С. Бандери, 12, Львів, Україна \\ orcid.org/0000-0002-6726-2537 \\ lozynskajuliya@yahoo.com
}

\author{
Ключові слова: \\ база практики, університет, \\ звіт, перекладацька \\ діяльність, щчоденник \\ проходження практики.
}

У статті проаналізовано процес проходження перекладацької практики як форми організації навчання студентів за освітньо-кваліфікаційним рівнем «Бакалавр». Висвітлено особливості організації перекладацької практики для студентів четвертого курсу спеціальності «Міжнародні відносини, суспільні комунікації та регіональні студії» Інституту гуманітарних та соціальних наук закладу вищої освіти технічного спрямування. Наголошено на важливості отримання практичного досвіду студентами на основі набутих у процесі теоретичного навчання знань та умінь. Виокремлено перекладацьку практику як одну із складових частин навчального процесу у вищій школі, що потребує деталізації та безпосередньо впливає на якість освіти студентів цієї спеціальності. Описано процедуру організації перекладацької практики починаючи від пошуку баз практики в різних сферах економічної діяльності, складання угод між Університетом та приймаючою організацією, формування наказу по Університету про направлення студентів на перекладацьку практику, ознайомлення із завданнями перекладацької практики, поставленими викладачами Університету, їх практичне виконання та реалізація на базах практики, підписання необхідної вихідної документації в організаціях та захист звіту після їі проходження на базі Університету з оформленням належним чином щоденника про проходження перекладацької практики та представленням виконаних завдань із копіями оригінальних документів, наданих організаціями для перекладу та опрацювання. Подано детальний зміст завдань перекладацької практики. Проаналізовано внесок перекладацької практики в навчальний процес закладу вищої освіти технічного спрямування за поданою вище спеціальністю та описано практичні рекомендації щодо вдосконалення процедури проходження перекладацької практики та можливостей урізноманітнення завдань із метою якісної підготовки фахівців та отримання конкурентоздатної вищої освіти та кваліфікації, що надалі забезпечить безпроблемне працевлаштування та реалізацію професійного потенціалу фахівця. 


\title{
PECULIARITIES OF TRANSLATION PRACTICE AS A FORM OF STUDENTS' EDUCATION ORGANIZATION OF THE TECHNICAL HIGHER EDUCATIONAL INSTITUTION
}

\author{
Matviyiv-Lozynska Yu. O. \\ Candidate of Pedagogical Sciences, Associate Professor, \\ Associate Professor at the Department of Foreign Languages \\ Lviv Polytechnic National University \\ Stepan Bandera str., 12, Lviv, Ukraine \\ orcid.org/0000-0002-6726-2537 \\ lozynskajuliya@yahoo.com
}

Key words:

practice base, university, report, translation activity, practice diary.
The article analyzes the process of translation practice as a form of students' education organizing according to the educational and qualification level "Bachelor". The peculiarities of the organization of translation practice for fourth-year students majoring in "International Relations, Public Communications and Regional Studies" of the Institute of Humanities and Social Sciences of the institution of technical higher education are highlighted. The importance of students gaining practical experience on the basis of knowledge and skills acquired in the process of theoretical learning is emphasized. Translation practice is singled out as one of the components of the educational process in higher education, which requires detail and directly affects the quality of education of students in this specialty. The procedure of organization of translation practice is described starting from search of bases of practice in various spheres of economic activity, drawing up the agreements between University and the accepting organization, formation of the order on University on the direction of students to translation practice, acquaintance with tasks of translation practice bases of practice, signing the necessary source documentation in organizations and defence of the reports after it on the basis of the University with proper diary of translation practice and presentation of completed tasks with copies of the original documents provided by organizations for translation and processing. The detailed content of the tasks of translation practice is given. The contribution of translation practice to the educational process of a higher education institution according to the mentioned above specialty is analyzed and practical recommendations are given to improve the procedure of translation practice and opportunities to diversify tasks to provide quality training and competitive higher education and qualifications, which will ensure trouble-free realization of professional potential of the specialist.
Постановка проблеми. У наш час здобуття вищої освіти ставить перед суспільством нові виклики та перспективи. Навчальний процес у закладі вищої освіти є багатогранним та охоплює різні форми організації навчання. Кожна з форм відіграє свою роль та робить значний внесок у розвиток фахівця.

$€$ багато класифікацій форм навчання в педагогічній науці. У нашому дослідженні ми спираємося на класифікацію Р. Піонової, згідно 3 якою форми навчання поділяються на теоретичні (лекція, семінар, консультація, навчальна екскурсія тощо), практичні (практикуми, лабораторні роботи), комбіновані (педагогічна та виробнича практика) та контрольні (іспит, залік) [1].
У поданому дослідженні ми розглядаємо одну 3 комбінованих форм організації навчання, а саме особливий вид педагогічної практики - перекладацьку практику. Студенти проходять іiі на четвертому курсі. Цю форму навчання називають комбінованою через поєднання теоретичних та практичних аспектів цієї дисципліни. На цьому етапі вже $\epsilon$ набуті студентами певні теоретичні знання та вміння 3 майбутньої професії. Під час практики є змога практично застосувати набуті знання та вміння.

Тематика проблеми перекладознавства в педагогічний науці $є$ порівняно новою, проте вже досліджуваною науковцями під різним кутом 
зору. В. Карабан досліджував основи перекладацької освіти. Є. Бесєдіна, К. Клауді вивчали особливості підготовки перекладачів у закладах вищої освіти. В. Комісаров, О. Мартинюк, О. Чередниченко розглядали проблеми формування професійної компетенції майбутніх фахівців із перекладознавства. Особливий інтерес для нашого дослідження становить робота науковця I. Горошкіна, який безпосередньо займався проблемою перекладацької практики як засобу формування мовної особистості перекладача. Дослідник вважає перекладацьку практику важливим складником навчального плану, метою якої $є$ підготовка студентів до подальшої професійної перекладацької діяльності [8, с. 36].

Як видно з вищенаведеного аналізу педагогічних праць, тематика дослідження особливостей перекладацької практики в закладах вищої освіти технічного спрямування не була предметом спеціального вивчення.

Мета статті - висвітлити особливості організації та проведення перекладацької практики в закладі вищої освіти технічного спрямування та окреслити практичні рекомендації щодо вдосконалення процедури проходження перекладацької практики та можливостей урізноманітнення завдань із метою якісної підготовки фахівців спеціальності «Міжнародні відносини, суспільні комунікації та регіональні студії».

Виклад основного матеріалу дослідження. Значення практичного навчання постійно зростає в освітньому просторі. Вміння застосовувати набуті знання та навички на практиці цінуються роботодавцями на ринку праці набагато більше та оплачуються вище. На основі вимог та тенденцій на ринку праці окреслюється певна орієнтація на здобуття практичних навичок у навчальному процесі, зокрема у закладах вищої освіти.

Під час теоретичних занять студенти мають змогу ознайомитися 3 теоретичним матеріалом тієї чи іншої дисципліни, новітніми досягненнями в науці. На практичних заняттях можна попрактикуватися в тому чи іншому аспектах теоретичного матеріалу детальніше.

Оскільки навчальний процес закладу вищої освіти передбачає певне чергування теоретичних та практичних занять, деяким студентам все одно не вистачає практичної імплементації набутих знань та деталізації практичних аспектів.

У статті ми зосереджуємо увагу на спеціальності «Міжнародні відносини, суспільні комунікації та регіональні студії», тому для студентів цієї спеціальності необхідно робити наголос саме на практичному аспекті, оскільки їхні знання з іноземної мови $є$ на достатньому рівні, а практика сприяє шліфуванню та вдосконаленню певних лексичних одиниць та граматич- них конструкцій, що є важливим у міжкультурній комунікації.

Предметом цього дослідження $є$ перекладацька практика в закладі вищої освіти як форма організації навчання, яка виконує надзвичайно важливу функцію формування комунікативної компетенції майбутнього фахівця у сфері міжнародних відносин.

Процес підготовки до перекладацької практики починається 3 пошуку баз практики, тобто місць проходження практики студентами. Бази практики обов'язково мають знаходитися в Україні, можна проходити практику за місцем проживання студентів. Якщо 3 певних причин студенти не можуть знайти місце проходження практики за місцем проживання, вони забезпечуються практикою через направлення з Університету.

Наступним етапом $є$ складання угод між Університетом та приймаючою організацією. Спеціально розроблена програма Університету дає змогу формувати угоди, досить швидко вносячи вручну реквізити приймаючої організації. Угоди мають бути підписані Університетом, а потім організаціями, де буде проходити перекладацька практика.

На початку проходження перекладацької практики викладачами Університету видаються спеціальні завдання, а саме: переклад 15 сторінок тексту з української мови англійською та 15 сторінок 3 англійської мови українською, складання анотацій англійською мовою та глосарію в кількості 100 термінів. Матеріали для перекладу надаються базами практики.

Студенти проходять перекладацьку практику на базах практики протягом трьох тижнів. Після закінчення практики студенти мають укласти щоденник проходження практики 3 виконаними завданнями та оригіналами документів на переклад. Глосарій має бути вивчений.

Звіт із перекладацької практики викладачі приймають на основі укладеного щоденника та вивченого глосарію. Студентам треба розповісти, що саме вони виконували під час проходження перекладацької практики на базі практики. Звіт приймається викладачами Університету протягом двох тижнів після закінчення практики.

Важливим елементом перекладацької практики $€$ правильність оформлення відповідного скерування по практиці, всі підписи та печатки мають бути на бланку скерування на перекладацьку практику від Університету. Без поданих елементів практика не вважається пройденою та не може бути оцінена належним чином викладачами Університету. Приймаюча організація подає характеристику на кожного студента та оцінює його роботу під час проходження перекладацької практики. 
Перекладацька практика дає змогу кожному студентові розкрити свій потенціал, за допомогою інструментарію іноземної мови попрактикуватися у письмовому перекладі, а також на вимогу організації - в усному синхронному чи послідовному перекладі. Під час проходження практики студенти мають змогу ознайомитися 3 різного виду документами та матеріалами сфери діяльності приймаючої організації та перекладати їх 3 української мови іноземною та навпаки.

Під час проходження перекладацької практики у студентів 3'являється змога зрозуміти, чи хочуть вони пов'язувати свою професійну діяльність 3 іноземною мовою, адже для студентів спеціальності «Міжнародні відносини, суспільні комунікації та регіональні студії» це одна 3 ключових дисциплін для подальшого розвитку особистості фахівця. Ця спеціальність є різноманітною та багатогранною та налічує багато аспектів діяльності. Студенти мають ще на стадії навчання зрозуміти, яку нішу зайняти у сфері своєї професійної діяльності та розвиватися в ній, щоб стати професіоналом та бути конкурентоздатним на ринку праці.

У поданому дослідженні ми маємо на меті не лише описати процедуру підготовки та проходження перекладацької практики студентами, але й окреслити практичні рекомендації щодо вдосконалення процедури проходження перекладацької практики та можливостей урізноманітнення завдань.

На нашу думку, з досвіду керування перекладацькою практикою студентів від Університету доцільно порекомендувати здійснювати пошук бази проходження практики ретельніше, щоб студенти розуміли специфіку діяльності та могли здійснювати переклад відповідних документів та матеріалів належним чином. Дуже часто студенти підбирають місце проходження практики за місцем проживання без прив'язування до спеціальності або діяльність підприємства не передбачає участі організації в кооперації з іноземними партнерами, тому якісних матеріалів для перекладу студентам не надають.

Під час складання словника фахових термінів (глосарія) студенти не завжди коректно вибирають терміни 3 оригінальних документів, наданих організаціями, і можуть вписати усі невідомі слова та поняття. Тому доцільно наголошувати на складанні глосарію $з$ термінів-іменників точно визначеної кількості.

Важливо не знівелювати процес проходження практики студентами, не перетворити його на формальність, бо студенти можуть втратити хорошу нагоду потренуватися в мистецтві перекладу та реально оцінити свої можливості та рівень набутих знань та умінь.

Щодо урізноманітнення завдань перекладацької практики, то вважаємо доцільним ввести аспект усного перекладу (синхронного або послідовного) певної інформації, представленої на базі практики або за піi відсутності - певного матеріалу з Інтернет-ресурсів, що відображає тематику, наближену до тієї, з якою працює подана організація. Усвідомлюємо, що це завдання ускладнить процес проходження перекладацької практики та приймання звіту за іiі результатами, проте це буде хорошою нагодою відчути себе перекладачем та спробувати свої сили в перекладознавстві.

Висновки. На основі вищевикладеного матеріалу можна зрозуміти важливість та доцільність навчального плану закладу вищої освіти технічного спрямування такої форми організації навчання, як перекладацька практика. Це своєрідний місток між теоретичними та практичними заняттями, де більша увага приділяється саме практичному аспекту засвоєння мови та тренуванню набутих теоретичних знань та умінь.

Для студентів спеціальності «Міжнародні відносини, суспільні комунікації та регіональні студіiі» однією з основних дисциплін у навчальному плані є іноземна мова, яка є джерелом комунікації між представниками різних етносів та народностей. Вивчення цієї дисципліни не може обмежуватися лише теорією, практика і застосування мови має надзвичайно велике значення в її засвоєнні та подальшому використанні.

Перекладацька практика на четвертому курсі сприяє інтенсивному використанню мови та вдосконаленню набутих навичок спілкування, перекладу, реферуванню спеціальної літератури іноземною мовою, практичним навичкам складання анотацій до поданої інформації, укладанню словника спеціальних термінів певного виду діяльності організації тощо.

Належним чином підготована та проведена перекладацька практика студентів спеціальності «Міжнародні відносини, суспільні комунікації та регіональні студії» сприяє вдосконаленню рівня володіння іноземною мовою студентів, наочно демонструє практичне застосування набутих знань та умінь та готовність до професійної діяльності в багатокультурному вимірі сьогодення.

До подальших розвідок зараховуємо дослідження практичних аспектів перекладацької практики та якісне урізноманітнення завдань для ii проходження студентами різних спеціальностей закладу вищої освіти технічного спрямування. 


\section{Література}

1. Пионова Р.С. Педагогика высшей школы : учеб. пособие. Минск : Вышэйшая школа, 2005. 303 с.

2. Карабан В.І. Переклад англійської наукової і технічної літератури [англ./укр.] : Навчальний посібник для ВНЗ. Вінниця : Нова Книга, 2004. 576 с.

3. Комиссаров В.Н. Современное переводоведение. Москва : Издательство,„ЭТС”, 2002. 424 с.

4. Мартинюк О.В. Проблеми професійної підготовки перекладачів у педагогічних дослідженнях вітчизняних та зарубіжних науковців. Народна освіта. 2011. Вип. 3(15). URL: http:// archive.nbuv.gov.ua/e-journals/NarOsv/2011-3/11movvzn.htm. (дата звернення: 26.08.2020).

5. Чередниченко О.І. Про мову і переклад : мова в соціокультурному просторі, переклад як міжкультурна комунікація. Київ : Либідь, 2007. 247 с.

6. Горошкін I.O. Перекладацька практика як засіб формування мовної особистості майбутніх перекладачів. Science and Education a New Dimension. Pedagogy and Psychology. Budapest. 2015. III (30). Issue: 59. C. 35-38.

\section{References}

1. Pionova, R.S. (2005) Pedagogika vysshey shkoly [Higher education pedagogy]. Minsk : Vysheyshaya shkola. (in Russian)

2. Karaban, V.I. (2004) Pereklad anhliys'koyi naukovoyi i tekhnichnoyi literatury [anhl./ukr.] [Translation of English scientific and technical literature [English/Ukrainian]]. Vinnytsya : Nova Knyha. (in Ukrainian)

3. Komissarov, V.N. (2002) Sovremennoe perevodovedenie [Modern translation studies]. Moskva : ETS. (in Russian)

4. Martynyuk, O.V. (2011) Problemy profesiynoyi pidhotovky perekladachiv u pedahohichnykh doslidzhennyakh vitchyznyanykh ta zarubizhnykh naukovtsiv [Problems of professional training of translators in pedagogical researches of national and foreign scientists]. Narodna osvita [Folk education] (electronic journal), Vol. 3(15). URL: (http://archive.nbuv.gov.ua/e-journals/NarOsv/2011-3/11movvzn.htm.) (accessed 26 August 2020).

5. Cherednychenko? O.I. (2007) Pro movu i pereklad : mova v sotsiokul'turnomu prostori, pereklad yak mizhkul'turna komunikatsiya [On language and translation: language in sociocultural space, translation as intercultural communication]. Kyyiv : Lybid'. (in Ukrainian)

6. Horoshkin? I.O. (2015) Perekladats'ka praktyka yak zasib formuvannya movnoyi osobystosti maybutnikh perekladachiv [Translation practice as a means of language personality of future translators]. Science and Education a New Dimension. Pedagogy and Psychology, vol. III (30), no. 59, pp. 35-38. 